\title{
PERAN ANALIS KREDIT TERHADAP NPL PADA PT X
}

\section{Achmad Fauzi}

Universitas BSI Bandung

A R T I C L E I N F O

Keywords : Credit, NPL (Non

Performing Loan)
Kata Kunci : $\quad$ Kredit, NPL (Non Performing Loan)

Corresponding author :

Achmad Fauzi

achmad_fauzioke@yahoo.com
Abstrack : PT. $x$ Indonesia is a company engaged in service. In carrying out its service, PT. X providing credit service to its customers. Data collection methods in the preparation of the final task is the method of observation, interviews, and research literature with analytical methods of qualitative analysis of data analysis methods without using statistical analysis. Credit disbursement activities one of them is using credit analysis, which plays an important role in minimizing any possibilities that cause credit to be problematic. From 2014 to 2016 the NPL has decreased significantly, in the process of submitting PT. X using 5C method (Character, Capacity, Capital, Collateral, Condition), this method is done to minimize NPL risk. Analyze credit in handling the risk of NPL incidence, PT. $X$ also take steps by always checking the progress of customers viewed from the payment every month. Because, the initial assessment of analyzing a credit is the current or not of the customer in performing the payment installment which is the responsibility of a customer.

Abstrak : PT. X Indonesia merupakan perusahaan yang bergerak di bidang jasa.Dalam menjalankan pelayanannya, PT. X Indonesia memberikan pelayanan kredit kepada para nasabah.Metode pengumpulan data dalam penyusunan Tugas Akhir adalah metode observasi, wawancara, dan penelitian kepustakaan dengan metode analisanya berupa analisis kualitatif yatitu metode analisis data tanpa menggunakan analisis

statistik.Kegiatanpenyalurankreditsalahsatudiantaranyaadalahmenggunakan analisiskredit,yang berperan penting dalam meminimalisir segala kemungkinan yang menyebabkankreditmenjadibermasalah. Pada tahun 2014 sampai tahun 2016 tingkat NPL mengalami penurunan yang signifikan, dalam proses pengajuan kredit PT. X menggunakan metode 5C (Character, Capacity, Capital, Collateral, Condition), metode ini dilakukan guna memperkecil risiko NPL. Menganilisis kredit dalam menanggulangi risiko timbulnya NPL, PT. X juga melakukan langkah dengan cara selalu mengecek perkembangan nasabah dilihat dari pembayaran setaip bulannya. Karena, penilaian awal dari menganalisis sebuah kredit adalah lancar tidaknya nasabah dalam melakukan cicilan pembayaran yang merupakan tanggung jawab seorang nasabah. NPL pada $X$ tahun 2014 sampai 2016 sebesar 2\% . 


\section{Latar Belakang}

\section{PENDAHULUAN}

Dalam perekonomian, kredit akan mengambil alih sebagian fungsi uang (yang digunakan untuk pembayaran tunai) karena hampir segala hal dilakukan dengan kredit. Maka peranan kredit dalam perekonomian modern yang seperti itu adalah kredit ternyata dapat meningkatkan efisiensi penggunaan uang atau modal dengan meningkatkan produktivitas masyarakat. Kredit dapat membantu proses produksi dari bahan hingga barang jadi dan sekaligus juga membantu pemindahan barang dari produsen kepada konsumen dalam proses marketing. Kegiatan penyaluran kredit salah satu diantaranya adalahan alisis kredit, yang berperan penting dalam meminimalisir segala kemungkinan yang menyebabkan kredititu menjadi bermasalah.

Dengan demikian, dilakukannya analisis kredit atau permohonan kredit yang disalurkan kepada para nasabah, guna tidak menjadi kredit macet atau kredit bermasalah (Non Performing Loan). Analisis kredit salah satu yang menggambarkan semua informasi yang berkaitan dengan usaha dan jasa pemohon termasuk penilaian atas kelayakan suatu permohonan pembiayaan guna terjadinya hal yang dapat merugikan perusahaan. Olehsebabitu, pembahasan ini pada dasarnya adalah untuk meneliti apakah pemohon memenuhi prinsip 5C atau tidak yang kemudian menjadi pertimbangan perusahaan untuk menentukan kelayakan pemohon kredit memperoleh kredit atau tidak, dengan perkataan lain apakah permohonan kredit tersebut feasible dalam artian dari kata-kredit diberikan, maka usahanya akan berkembang baik dan mampu mengembalikank redit, baik pokok maupun bunga dalamjangka waktu yang wajar atau sebaliknya.

Pengelolaan kredit bermasalah atau NPL (Non Performing Loan) menjadi sangat penting karena hal ini berdampak pada kinerja perusahaan, NPL ini menunjukan seberapa besar kolektibilitas perusahaan dalam mengumpulkan kembali kredit yang telah disalurkan.Tingginyanilai NPL dapat mempengaruhi kebijakan perusahaan dalam menyalurkan kreditnya. Kualitas kredit dinilai berdasarkan kolektibilitasnya yang pada prinsipnya berdasarkan pada kontinuitas pembayaran oleh debitur. Berdasarkan peraturan Bank Indonesia No. 31/147/KEP/DIR tanggal 12 November 1998 tentang kualitas aktiva produktif, maka kualitas kredit dapat digolongkan menjadi lancar (pass), dalam perhatian khusus (special mention), kurang lancar (substandard), diragukan (doubtfull) dan macet (loss).

Peningkatan kredit bermasalah atau Non Performing Loan (NPL) yang dialami perbankan nasional mengakibatkan bank kehilangan kemampuannya dalam menghasilkan laba yang optimum dari kegiatan pokoknya tersebut. Dengan meningkatnya kredit bermasalah, maka dampak positif yang ditimbulkan oleh penyaluran kredit tidak dapat terjadi. Hal ini dikarenakan pendapatan operasional dari pemberian kredit sangat kecil karena bunga yang seharusnya diterima oleh bank dari penyaluran kredit tidak diterima secara penuh.

\section{Tujuan Penelitian}

Tujuan penelitian ini untuk mengetahui Peran NPL Terhadap Laporan Keuangan pada PT Home Krefit.

\section{Pembiayaan}

\section{KAJIAN PUSTAKA}

Menurut Ayus dan Aziz (2009 : 67) "Berbeda dengan pengertian kredit yang mengharuskan debitur mengembalikan pinjaman dengan pemberian bunga kepada bank, maka pembiayaan berdasarkan prinsip syariah pengembalian pinjaman dengan bagi hasil berdasarkan kesepakatan antara bank dan debitur." Menurut Rivai (2010:681) memberikan batasan bahwa "pembiayaan adalah pendanaan yang diberikan oleh suatu pihak ke pihak lain untuk mendukung investasi yang telah direncanakan, baik dilakukan sendiri atau lembaga." Menurut UU No.10 tahun 1998 memberikan batasan bahwa"pembiayaan adalah penyediaan uang atau tagihan yang dapat dipersamakan dengan itu, berdasarkan persetujuan atau tagihan antara bank dengan pihak lain yangmewajibkan pihak yang dibiayai untuk mengembalikan uang atau tagihan tersebut setelah jangka waktu tertentu dengan imbalan atau bagi hasil".

Menurut UU No. 21 tahun 2008 tentang perbankan syariah pasal 1 poin memberikan batasan bahwa "Pembiayaan adalah penyediaan dana atau tagihan yang dipersamakan berupa transaksi bagi hasil,transaksi sewa menyewa,transaksi jual beli,dan transaksi pinjam meminjam". 


\section{Jenis-Jenis Pembiayaan}

Menurut Remy (2014:418) ada beberapa modal pembiayaan pada perbankan, yaitu :

1. Pembiayaan untuk tujuan modal kerja

Pembiayaan ini dilakukan untuk memfasilitasi perdagangan atau mencukupi kebutuhan modal kerja bagi para nasabahnya, dengan menyediakan fasilitas modal kerja untuk pembelian barang, mesin atau segala hal yang berhubungan dengan modal kerja.

2. Pembiayaan untuk kebutuhan konsumtif

Pembiayaan jangka pendek (short term finance) ini dilakukan untuk pemenuhan-pemenuhan kebutuhan konsumtif nasabah, seperti pembelian rumah, kendaraan bermotor / mobil yang memang sifatnya ingin digunakan secara pribadi.

3. Pembiayaan multiguna

Pembiayaan multiguna ini ialah pembiayaan yang dilakukan untuk memenuhi kebutuhan nasabah yang tidak termasuk kedalam kategori modal kerja ataupun konsumtif namun tidak bertentangan dengan syariah islam.

4. Pembiayaan sektor pertanian

Dalam kegiatan pertanian bank juga dapat berpatisipasi dalam bentuk pembiayaan yang berdasarkan muzara'ah.

\section{Fungsi Pembiayaan}

Pembiayaan memliki fungsi yang beragam, menurut Rivai (2010:683) fungsi pembiayaan antara lain adalah sebagai berikut :

1. Memberikan pembiayaan dengan prinsip syariah yang menerapkan sistem bagi hasil yang tidak memberatkan debitur.

2. Membantu kaum dhuafa yang tidak tersentuh oleh bank konvensional karena tidak mampu memenuhi persyaratan yang ditetapkan oleh bank konvensional.

3. Membantu masyarakat ekonomi lemah yang selalu dipermainkan oleh rentenir dengan membantu melalui pendanaan untuk usaha yang dilakukan.

Selain fungsi diatas, adapun pembiayaan memiliki fungsi yaitu sebagai berikut:

1. Meningkatkan daya guna uang.

2. Meningkatkan daya guna barang.

3. Meningkatkan peredaran uang.

Setelah melihat beberapa fungsi diatas, bisa terlihat adanya pembiayaan dalam sebuah bank dan lembaga keuangan juga untuk meningkatkan peredaran uang di masyarakat, sehingga bank sebgai lembaga intermediasi antara pihak surplus dengan pihak deficit mampu bekerja secara optimal.

\section{Kredit}

Menurut Hariyani (2010:10) menyatakan "kredit yang diberikan oleh bank didasarkan atas kepercayaan sehingga pemberian kredit merupakan pemberian kepercayaan kepada nasabah”. Pengertian kredit menurut UU No. 10 Tahun 1998 tentang perubahan UU No. 7 Tahun 1992 menyimpulkan bahwa:

Kredit adalah penyediaan uang atau tagihan-tagihan yang dapat dipersamakan dengan itu berdasarkan persetujuan atau kesepakatan pinjam-meminjam antara bank dengan pihak lain yang mewajibkan pihak peminjam melunasi utangnya setelah jangka waktu tertentu dengan pemberian bunga”.

Menurut Pedoman Akuntansi Perbankan Indonesia (PAPI) 2001 menyimpulkan bahwa:

Kredit adalah penyediaan uang atau tagihan yang dapat dipersamakan dengan itu, berdasarkan persetujuan atau kesepakatan pinjam-meminjam antara bank dan pihak lain yang mewajibkan pihak peminjam (debitur) untuk melunasi hutangnya setelah jangka waktu tertentu dengan jumlah bunga, imbalan atau pembagian hasil keuntungan.

Tujuan Kredit

Pemberian suatu fasilitas kredit mempunyai tujuan tertentu. Tujuan pemberian kredit tersebut tidak akan terlepas dari misi bankatau perusahaan tersebut didirikan.Menurut Kasmir (2014:88) adapun tujuan utama pemberian suatu kredit antara lain : 
1. Mencari keuntungan

Yaitu bertujuan untuk memperoleh hasil dari pemberian kredit tersebut.Hasil tersebut terutama dalam bentuk bunga yang diterima oleh Bank sebagai balas jasa biaya administrasi yang dibebankan kepada nasabah.

2. Membantu usaha nasabah

Tujuan lainnya adalah untuk membantu usaha nasabah yang memerlukan dana, baik dana investasi maupun dana modal kerja. Dengan dana tersebut, maka pihak debitur akan dapat mengembangkan dan memperluas usahanya.

3. Membantu pemerintah

Bagi pemerintah semakin banyak kredit yang disalurkan oleh pihak perbankan, maka semaikin baik, mengingat banyak kredit berarti adanya peningkatan pembangunan diberbagai sektor.

\section{Fungsi Kredit}

Kemudian disamping tujuan diatas, suatu fasilitas kredit menurut Rivai (2013:7) memiliki fungsi sebagai berikut :

1. Kredit dapat meningkatkan utility (daya guna) dari modal / uang.

2. Kredit meningkatkan utility (daya guna) suatu barang.

3. Kredit meningkatkan peredaran dan lalu lintas uang.

4. Kredit menimbulkan kegairahan berusaha masyarakat

5. Kredit sebagai alat stabilitas ekonomi.

6. Kredit sebagai jembatan untuk peningkatan pendaptan nasional

7. Kredit sebagai alat hubungan ekonomi internasional.

\section{Analisa Kredit}

Menurut Supriyono (2011:161) memberikan batasan bahwa "proses analisis kredit mempunyai tujuan utama yang paling hakiki, yaitu agar bankmembuat satu keputusan kredit yang baik dan benar (make a good loan), sehingga terhindar dari keputusan kredit yang keliru yang menyebabkan kredit bermasalah (bad loan)".Rivai (2013:249) memberikan batasan bahwa "analisis kredit adalah penelitian yang dilakukan oleh account officer terhadap kelayakan perusahaan, kelayakan usaha nasabah, kenutuhan kredit, kemampuan menghasilkan laba, sumber pelunasan kredit serta jaminan yang tersedia untuk meng-cover permohonan kredit".Ismail (2010:111) menyimpulkan bahwa:analisis kredit adalah suatu proses analisis kredit yang dilakukan oleh bank untuk menilai suatu permohonan kredit yang telah diajukan oleh calon debitur. Analisis yang baik akan menghasilkan keputusan yang tepat, sehingga analisis kredit merupakan salah satu faktor yang sangan penting dalam keputusan kredit.

\section{Tujuan Analisa Kredit}

Fahmi (2008:13) prinsip 5C yaitu meliputi :

1. Character (Karakteristik)

Adalah keadaan watak dari nasabah, baik dalam kehidupan pribadi maupun dalam lingkungan usaha.

2. Capacity (Kemampuan)

Adalah kemampuan yang dimiliki calon nasabah dalam menjalankan usahanya guna memperoleh laba yang diharapkan.

3. Capital (Modal)

Adalah jumlah dana/modal sendiri yang dimiliki oleh calon nasabah.semakin besar modal sendiri dalam perusahaan, tentu semakin tinggi kesungguhan calon nasabah dalam menjalankan usahanya dan bank akan merasa lebih yakin dalam memberikan kredit

4. Collateral (Jaminan)

Adalah barang-barang yang diserahkan nasabah sebagai agunan terhadap kredit yang diterimanya.

5. Condition of economy (Kondisi perekonomian)

Yaitu situasi dan kondisi politik, sosial ekonomi, budaya yang mempengaruhi keadaan perokonomian pada suatu saat yang kemungkinannya memengaruhi kelancaran perusahaan calon debitur. 


\section{NPL (Non Performing Loan)}

Menurut Rivai (2013:398) memberikan batasan bahwa "kredit bermasalah adalah kredit yang di dalam pelaksanaannya belum mencapai / memenuhi target yang diinginkan oleh pihak bank".Menurut Hariyani (2010:35) memberikan batasan bahwa "kredit bermasalah ialah kredit yang tergolong kredit yang kurang lancar, kredit diragukan, dan kredit macet".Menurut Kuncoro dan Suharjono dalam Ismail (2010:222) memberikan batasan bahwa "kredit bermasalah adalah suatu kedaan dimana nasabah sudah tidak sanggup membayar sebagian atau seluruh kewajibannya kepada bank seperti yang telah dijanjikan".

Penyelasaian Non Performing Loan

Menurut Rivai (2013:403), "Penyelesaian kredit adalah upaya yang dilakukan bank akan menyelesaikan kredit bermasalah yang tidak mempunyai prospek setelah usaha-usaha pembinaan, penyelamatan, dan dengan jalan apapun ternyata tidak mungkin dilakukan lagi, dengan tujuan untuk mencegah resiko bank yang semakin besar serta mendapat pelunasan kembali atas kredit tersebut dari debitur dengan berbagai macam upaya yang dapat ditempuh oleh bank".

\section{Penelitian Terdahulu}

Mandala dan Fransiscus ( 2012 ), Penilaian risiko kredit untuk pinjaman terjamin adalah biaya operasi yang penting dalam sistem perbankan untuk memastikan kreditur membayar pinjamannya. Untuk memastikan bank dapat berkinerja baik. Penelitian ini bertujuan untuk mengidentifikasi faktor-faktor yang ada pada Bank Perkreditan Rakyat dalam menilai aplikasi kredit yang diberikan. Dengan tujuan mengurangi jumlah kredit macet, kriteria keputusan saat ini pada penilaian risiko kredit dievaluasi. Selanjutnya, model pohon keputusan diusulkan dengan menerapkan metodologi penambangan data. Model penilaian risiko kredit diterapkan pada PT BPR X di Bali yang memiliki 1082 kreditur (11,99\%) yang memiliki kinerja buruk pinjaman dan diidentifikasi sebagai kasus kredit macet. Ini membuat PT BPR X dikategorikan sebagai bank yang berkinerja buruk. Penambangan data digunakan untuk menyarankan model pohon keputusan untuk penilaian kredit karena dapat menunjukkan apakah permintaan pemberi pinjaman dapat diklasifikasikan sebagai risiko kredit bermasalah atau non-performing. Menggunakan metodologi C 5.0, model pohon keputusan baru dihasilkan. Model ini menunjukkan bahwa kriteria baru dalam menganalisis aplikasi pinjaman. Hasil evaluasi menunjukkan bahwa jika ini model yang diterapkan, PT BPR X dapat mengurangi kredit macet hingga kurang dari 5\% dan bank dapat digolongkan sebagai bank berkategori baik.

\section{Hipotesis Penelitian}

Non performing loan atau kredit bermasalah merupakan salah satu indicator kunci untuk menilai kinerja fungsi perusahaan. Ini artinya NPL merupakan indiakasi adanya masalah dalam perusahaan tersebut yang mana jika tidak segera mendapatkan solusi maka akan berdampak bahaya bagi perusahaan. Bagaimana tidak, meningkatnya NPL ini jika dibiarkan secara terus menerus maka akan memberikan pengaruh negatif pada perusahaan.

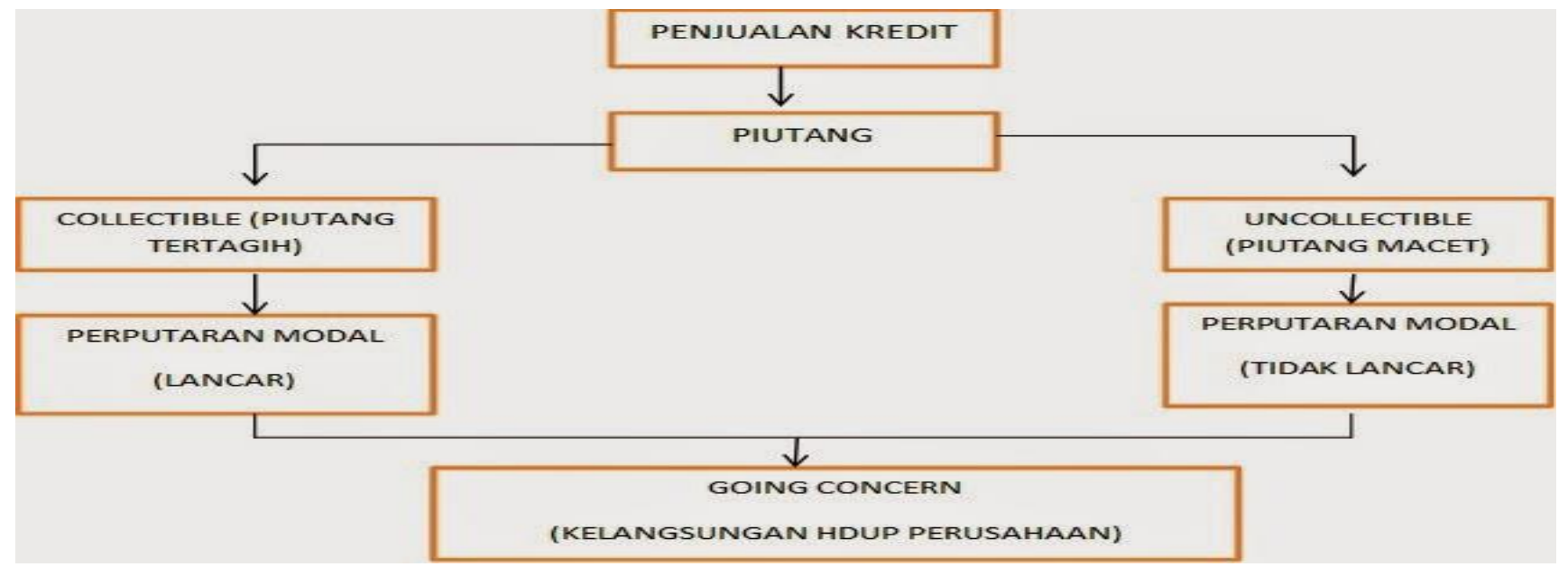

Gambar1. Kerangka Pemikiran 
Akan terjadi NPL jika dilihat dari Piutang artinya banyaknya piutang tidak tertagih akan berdampak pada kredit macet, dan perputaran piutang yang tidak lancar akan sangat menentukan kelangsungan hidup perusahaan kedepan

\section{Jenis Penelitian}

\section{METODE PENELITIAN}

Analisis data penelitian kualitatif dapat dilakukan melalui tiga alur kegiatan yang terjadi secara bersamaan yaitu: 1) reduksi data (data reduction), 2) penyajian data (data displays dan 3) penarikan kesimpulan/verifikasi (conclusion drawing/veriffication). Dalam penelitian ini peneliti menggunakan analisis deskriptif dengan menerangkan proses berfikir induktif yaitu berangkat dari faktor- faktor khusus, peristiwa-peristiwa yang konkrit kemudian dari faktor-faktor atau peristiwa yang khusus dan konkrit kemudian itu ditarik generalisasi yang bersifat umum ( Miles\& Huberman, 2009).

\section{Populasi dan Sampel}

Populasi dan sampel pada penelitian ini adalah data laporan piutang perusahaan. Dimana sampel yang diambil terdiri dari Piutang tidak tertagih, piutang tertagih dan penghapusan piutang.

\section{Metode Analisis}

Metode analisa yang digunakan adalah penelitian kualitatif dengan studi kasus. Fokus penelitian pada NPL dengan Sub fokus penelitian pada piutang tertagih, piutang tidak tertagih dan penghapusan piutang.

\section{Hasil Penelitian}

\section{HASIL PENELITIAN DAN PEMBAHASAN}

Sebagaimana yang telah di jabarkan diatas bahwa NPL bisa memberikan pengaruh besar pada perusahaan.NPL yang juga dikenal dengan kredit bermasalah ini memang bisa berdampak pada berkurangnya modal bank. Jika hal ini dibiarkan, maka yang pasti akan berdampak pada penyaluran kredit pada periode berikutnya. Jika kreditur tidak lagi memenuhi kewajibannya membayar angsuran, maka bisa dipastikan perusahaan akan mengalami kehilangan sumber incomenya. Akibatnya, kondisi ini akan mengurangi kondisi deviden dan juga laba.NPL yang tinggi juga mengakibatkan tidak bekerjanya fungsi intermediasi perusahaan secara optimal karena menurunkan perputaran dan perusahaan perusahaan sehingga memperkecil kesempatan perusahaan memperoleh pendapatan. Dengan kata lain NPL menurunkan profitabilitas perusahaan.

Bank Indonesia (BI) melalui Peraturan Bank Indonesia (PBI) menetapkan bahwa rasio kredit bermasalah (NPL) adalah sebesar 5\%. Rumus perhitungan NPL adalah sebagai berikut :

$$
\text { Rasio NPL }=(\text { Total NPL / Total Kredit }) \times 100 \% 100 \%
$$

Pasal 4 Bank Indonesia menetapkan bank dalam pengawasan intensif jika dinilai memiliki potensi kesulitan yang membahayakan kelangsungan usahanya. Bank dinilai memiliki potensi yang membahayakan kelangsungan usahanya sebagaimana yang dimaksud pada ayat (1) jika memenuhi satu atau lebih kriteria seperti berikut :

Tabel. 1 Tingkat Standar NPL Pada Bank Indonesia

\begin{tabular}{lcl}
\hline \multicolumn{1}{c}{ Kriteria } & Peringkat & \\
\hline $\mathbf{N P L}<\mathbf{2 \%}$ & 1 & Nilai \\
$\mathbf{2 \%}<\mathbf{N P L} \leq \mathbf{5 \%}$ & 2 & Baik \\
$\mathbf{5 \%}<\mathbf{N P L} \leq \mathbf{8 \%}$ & 3 & Cukup Baik \\
$\mathbf{8 \%}<\mathbf{N P L} \leq \mathbf{1 2 \%}$ & 4 & Kurang Baik \\
$\mathbf{N P L}>\mathbf{1 2 \%}$ & 5 & Tidak Baik \\
\hline
\end{tabular}


Tabel 2. Hasil perhitungan NPL periode Tahun 2014-2016

\begin{tabular}{lccc}
\multicolumn{1}{c}{ Tahun } & $\mathbf{2 0 1 4}$ & $\mathbf{2 0 1 5}$ & $\mathbf{2 0 1 6}$ \\
\hline NPL & 3.551 .238 .392 & 2.702 .638 .917 & 1.735 .970 .845 \\
KREDIT & 75.159 .753 .566 & 86.681 .335 .328 & 146.558 .356 .710 \\
RASIO NPL & $5 \%$ & $3 \%$ & $1 \%$ \\
\hline
\end{tabular}

Uraian perhitungan NPL periode tahun $2014-2016$ adalah sebagai berikut :

1. Tahun 2014

$$
\begin{aligned}
\text { Rasio NPL }= & (\text { Total NPL } / \text { Total Kredit }) \times 100 \% \\
& 3.551 .238 .392: 2.702 .638 .917 \\
& 1.31 \times 100 \% \\
= & 5 \%
\end{aligned}
$$

Berdasarkan uraian perhitungan yang telah dilakukan NPL pada tahun 2014 sebesar 5\%, jika dilihat dari tingkat standar NPL pada Bank Indonesia hal ini menunjukkan NPL pada PT. X periode tahun 2014 dikatakan cukup baik dalam menjaga kesehatan perusahaan.

2. Tahun 2015

$$
\begin{aligned}
\text { Rasio NPL }=(\text { Total NPL } / \text { Total Kredit }) \times 100 \% & \\
& 2.702 .638 .917: 86.681 .335 .328 \\
& 0.03 \times 100 \% \\
& =3 \%
\end{aligned}
$$

Berdasarkan uraian perhitungan yang telah dilakukan NPL pada PT X periode tahun 2015 mengalami tingkat penurunan sebesar 2\% sehingga tingakt NPL pada X menjadi sebesar 3\%, jika dilihat dari tingkat standar NPL pada Bank Indonesia hal ini menunjukkan NPL pada PT X periode tahun 2015 dikatakan baik dalam menjaga kesehatan perusahaan.

3. Tahun 2016

$$
\begin{aligned}
& \text { Rasio NPL }=(\text { Total NPL } / \text { Total Kredit }) \times 100 \% \\
& \\
& 1.735 .970 .845: 146.558 .356 .710 \\
& 0.01 \times 100 \% \\
&=1 \%
\end{aligned}
$$

Berdasarkan uraian perhitungan yang telah dilakukan NPL pada X periode tahun 2016 mengalami tingkat penurunan sebesar 2\% sehingga tingakt NPL pada X menjadi sebesar 1\%, jika dilihat dari tingkat standar NPL pada Bank Indonesia hal ini menunjukkan NPL pada X periode tahun 2016 dikatakan sangat baik dalam menjaga kesehatan perusahaan.

Jadi Non Performing Loan (NPL) pada penelitian ini mempunyai pengaruh yang signifikan dalam berperan menjaga kesehatan perusahaan, bisa dilihat dari perhitungan NPL dari periode tahun 2014 ke 2015 mengalami penurunan sebesar 2\% dan 2015 ke 2016 mengalami penurunan sebesar 2\%, penurunan dalam NPL ini menununjukkan kemajuan dalam upaya menjaga kesehatan peusahaan. Hal ini bisa disebabkan oleh faktor seperti PT X bisa mengatasi masalah kredit macet, atau juga sebuah itikad baik dari pihak debitur sendiri.

\section{Pembahasan}

Berdasarkan hasil penelitian observasi, menganilisis kredit dalam menanggulangi risiko timbulnya NPL, PT $\mathrm{X}$ melakukan langkah dengan cara selalu mengecek perkembangan nasabah dilihat dari pembayaran setaip bulannya. Karena, penilaian awal dari menganalisis sebuah kredit adalah lancer / tidaknya nasabah dalam melakukan cicilan pembayaran yang merupakan tanggung jawab seorang nasabah.

Nasabah sudah mengalami kemacetan dalam melakukan pembayaran pokok, maka dari itu, PT X selanjutnya harus lebih melakukan penilaian yang layak sebelum memberikan persetujuan prinsip atau final appaun untuk memberikan pinjaman apapun kepada nasabah tersebut jika melakukan pengajuan kredit kembali.

Apabila kredit tersebut sudah macet, PT X lebih melakukan tindakan penagihan pertanggung jawaban dengan mewajibkan nasabah untuk membayar denda atau ganti rugi jika sudah terlambat melakukan pembayaran kredit. 


\section{Peranan Analisis Kredit Dalam Menjaga Proses Pengajuan Kredit}

Sebagai pihak yang bertindak menjadi kreditur, maka sudah sepatutnya PT $\mathrm{X}$ memiliki kriteria dan penggolongan terhadap kualitas kredit yang di keluarkan. Hal ini dimaksudkan untuk mempermudah proses klasifikasi dan penanganan terhadap berbagai macam permasalahan yang mungkin saja timbul dalam sebuah perjanjian kredit yang telah dilakukan.

Pada dasarnya banyak hal yang menjadi faktor pendukung dalam timbulnya kredit macet, hal ini tentu saja berawal dari pihak perusahaan yang bertindak sebagai kreditur / pemberi pinjaman tersebut.

Untuk menganalis proses pengajuan kredit yang nasabah ajukan, PT X sendiri memiliki langkah-langkah untuk mengantisipasi risiko timbulnya kemactean kredit nantinya yang dapat membuat perusahaan mengalami kerugian.Berdasarkan catatan laporan observasi bahwa dalam menganalis suatu permohonan kredit agar memperkecil ataupun menghindari dari kredit bermasalah atau macet, perusahaan yang melakukan analisa terhadap permohonan kredit tersebut dengan memeriksa dari keterangan seperti penghasilan calon nasabah, pekerjaan calon nasabah. Serta melihat record calon nasabah dari BI Checking. Perusahaan memang harus sedini mungkin mengantisipasi risiko yang mungkin akan timbul dimasa yang akan datang dengan melakukan pengawasan kredit agar memperkecil risiko-risiko yang dapat merugikan perusahaan.

\section{PENUTUP}

\section{Kesimpulan}

Berdasarkan penjelasan dari hasil penelitian dan pembahasan yang telah dilakukan oleh peneliti, maka dapat disimpulkan sebagai berikut:

1. Non Performing Loan (NPL) merupakan salah satu kunci indikator untuk menilai kinerja fungsi perusahaan. Dengan meningkatnya NPL jika dibiarkan akan memberikan pengaruh negative pada perusahaan dimana dampak negative tersebut salah satunya adalah mengurangi jumlah modal yang dimiliki pada perusahaan. Untuk menjaga perusahaan tetap aman, maka sistem manajemen yang baik perlu diterapkan secara maksimal. NPL yang tinggi akan mengakibatkan tidak bekerjanya fungsi intermediasi perusahaan secara optimal. Bank Indonesia telah menetapkan bahwa rasio kredit bermasalah (NPL) adalah sebesar 5\%. Berdasarkan hasil dari perhitungan NPL yang telah didapat pada tahun 2014 sebesar 5\%, kemudian mengalami penurunan pada tahun 2015 sebesar 3\%, dan pada tahun 2016 kembali mengalami penurunan sebesar 1\%. Dengan terjadinya penurunan dari tahun ke tahun ini dapat menunjukkan kemajuan dalam upaya menjaga kesehatan perusahaan.

2. Peranan analisis kredit dalam menanggulangi risiko karena NPL merupakan penilaian terhadap kredit yang terkadang didalam pemberian kreditnya tidak memperhatikan ketelitian dan ketetapan yang ada. Kemampuan perusahaan dalam mengelola kredit yang disalurkan memiliki pengaruh terhadap stabilitas dan keberhasilan usaha perusahaan secara keseluruhan. Dalam jangka pendek kredit dapat mendatangkan kerugian besar. Oleh karena itu, diperlukan adanya penilaian awal permohonan kredit dari debitur. Analisis kredit berpengaruh terhadap potensi terjadinya kredit bermasalah atau kredit macet. Berdasarkan hasil observasi bahwa menganalisis kredit dalam menanggulangi risiko timbulnya NPL PT.X melakukan langkah dengan cara selalu mengecek perkembangan nasabah jika dilihat dari pembayaran setiap bulannya.

Sebagai pihak yang bertindak menjadi kreditur, PT.X memiliki kriteria dan penggolongan terhadap kualitas kredit yang dikeluarkan. Pada dasarnya banyak hal yang menjadi faktor pendukung dalam timbulnya sebuah kredit macet. Untuk menganalisis proses dalam pengajuan kredit yang diajukan oleh nasabah, maka PT.Home Credit memiliki langkah-langkah untuk mengantisipasi risiko timbulnya kemacetan kredit nantinya yang dapat membuat suatu perusahaan mengalami kerugian. Berdasarkan catatan laporan observasi bahwa dalam menganalisis suatu permohonan kredit dalam menghindari kredit bermasalah atau macet. Maka, perusahaan melakukan analisa terhadap permohonan kredit dengan memeriksa sebuah keterangan seperti penghasilan dan pekerjaan calon nasabah. 


\section{Saran}

Berdasarkan hasil penelitian dan pembahasan di atas, maka penulis memberi saran sebagai berikut :

1. PT.Home Credit harus selalu mengecek pembayaran nasabah setiap bulannya untuk menjaga agar tidak terjadinya kredit macet atau kredit bermasalah. Perusahaan dapat mengantisipasi untuk memperkecil risikorisiko yang terjadi dalam pemberian kredit yaitu dengan cara melihat penghasilan dari calon nasabah. Risiko yang sering terjadi dalam pemberian kredit adalah para nasabah yang memiliki tunggakan pembayaran. Kemudian langkah yang dapat diambil oleh perusahaan apabila nasabah mengalami kredit macet yaitu dengan cara menarik kembali barang yang sudah dikreditkan kepada nasabah. Tindakan yang dapat diambil jika pemberi kredit menghadapi kredit yang bermasalah yaitu apabila kredit sudah tidak bisa diselamatkan maka perusahaan akan menyelesaikan dengan proses hukum yang berlaku.

2. Pertimbangan dalam kelayakan permohonan kredit yaitu kelayakan untuk pencairan kredit PT.Home Credit menilai dari segi penghasilan dan juga melihat dari BI Checking. Ukuran keberhasilan dalam pemberian kredit adalah apabila nasabah tidak menunggak pembayaran selama proses kredit berlangsung. Itikad tidak baik, kesalahan dari peminjam itu sendiri dan situasi dan kondisi pada umumnya adalah penyebab terjadinya tunggakan kredit. Dalam melakukan penilaian dan penganalisaan suatu permohonan kredit harus ada beberapa aspek diantaranya yaitu adanya aspek ekonomis dan aspek finansial.

\section{DAFTAR PUSTAKA}

Arviyan, Arifin dan Rivai, Veitzhal. 2010. Islamic Banking. Jakarta: PT. Bumi Aksara

Fahmi, Irham. 2008. Analisis Kredit Dan Fraud. Jakarta: Alumni

Hariyani, Iswi. 2010. Restrukturasi Dan Penghapusan Kredit Macet. Jakarta: Elex Media Komputindo

Hantono. 2017. Faktor Yang Mempengaruhi Profitabilitas Pada Perusahaan Property Dan Real Estate Yang Terdaftar Di Bei Periode 2012 -2015. Jurnal Manajemen Bisnis dan Inovasi. Vol. 5 No. 1. https://ejournal.unsrat.ac.id/index.php/jmbi/article/view/19147/18705

Ismail. 2010. Akutansi Bank. Jakarta: Kencana

Indonesia, Home Credit. 2013. Home Credit Tentang Kami. Jakarta

Kasmir. 2014. Bank Dan Lembaga Keuangan Lainnya. Jakarta: PT. RajaGrafindo Persada

Maryanto, Supriyono. 2011. Buku Pintar Perbankan. Yogyakarta: Andi Yogyakarta

Miles, Matthew.2014. Analisis Data Kualitatif. Jakarta: Universitas Indonesia.

Sjahdeini, Sutan Remy. 2014. Perbankan Syariah. Jakarta: Kencana Pernadamedia Group

Veithzal, Andria Permata dan Rivai, Veithzal. 2013. Credit Management Handbook Manajemen Perkreditan. Jakarta: PT. RajaGrafindo Persada

Zainuddin, Ali. 2008. Hukum Perbankan Syariah. Jakarta: Sinar Grafika

Tulung, Joy Elly., and Ramdani, Dendi (2016). The Influence of Top Management Team Characteristics on BPD

Performance. International Research Journal of Business Studies, Volume 8 Nomor 3, 155-166. http://irjbs.com/index.php/jurnalirjbs/article/view/1147

Tulung, Joy Elly., and Dendi Ramdani. 2018. Independence, Size and Performance of the Board: An Emerging

Market Research. Corporate Ownership \& Control, Volume 15, Issue 2, Winter 2018. 